Article

\title{
Freeports and the Hidden Value of Art
}

\author{
John Zarobell \\ Department of International Studies, University of San Francisco, San Francisco, CA 94117, USA; \\ jzarobell@usfca.edu
}

Received: 25 August 2020; Accepted: 12 November 2020; Published: 18 November 2020

check for updates

\begin{abstract}
At first glance, the global art trade—currently valued around $\$ 60$ billion—is a miniscule piece of global economic production. But due to the unregulated nature of the art market, it serves a key function within the larger network of the accumulation and distribution of capital worldwide. This deregulated market intersects with the offshore domain in freeports, an archipelago of tax-free storage facilities that stretch from Singapore to Geneva to Delaware. The burgeoning of freeports globally suggests that speculation has become a more prominent pattern of art investment, but it also demonstrates that tax avoidance is a goal of such speculators and the result is that more art works are being taken out of circulation and deposited in vaults beyond the view of regulatory authorities. Despite its size, the art trade can demonstrate broader trends in international finance and, by examining offshore art storage that occurs in freeports, it will be possible to locate some of the hidden mechanisms that allow the global art market to flourish on the margins of the economy as well as to perceive a shift in which the economic value of art works predominates over their cultural value.
\end{abstract}

Keywords: art market; contemporary art; freeports; offshore; financialization; informality

\section{Introduction}

Freeports are a subsector of the deterritorialized spaces that states have created to facilitate transnational commerce since World War II, usually called Export Processing Zones (EPZs) or Free Trade Areas/Zones (FTAs/FTZs) but sometimes, as in the Bahamas, these are also called freeports. In the banking sector, these spaces of national exception are referred to as "offshore" because the activities that take place there are subject to different regulations than the statutory laws of the host country, including tax advantages for investors. The burgeoning of freeports globally, as distinct from the consistent presence of bonded warehouses for other types of merchandise, suggests that buying art is no longer solely connected to the social status it once conferred. Rather, the art market has evolved to the point that many buyers are investing in an asset class ${ }^{1}$, one in need of protection from taxation and regulatory scrutiny as with offshore banking. The result is that more art works are being taken out of circulation and deposited in freeport vaults, no longer adorning the homes of the collectors who purchased them. While art is widely considered a public good, and museums that present it to the public are worthy of state subsidy, freeports that sequester art reveal a market domain in which works of art are embedded. A number of news reports (Ford 2019; Kosmides 2019; Nixey 2019) have underlined the cultural problem of removing art from the public domain since the cultural capital of an art work, when deposited in a public institution, is shared with many and not preserved for the few. By storing art in freeports, collectors trade in cultural capital for the benefit of tax-free investment and

1 The use of the term "asset class" to refer to art has become relatively common, being cited in studies of freeports by the EU (see Korver 2018), the trade press on the art market, such as the Art Newspaper and the Financial Times, in studies of the art market conducted by Deloitte and ArtTactic (see Deloitte and ArtTactic 2014, 2019) and also by academics (See Horowitz 2011; Coslor and Velthuis 2012; Zarobell 2015). 
reinvestment and it could be said that the cultural idea of a collector is being superseded. While art continues to provide cultural capital in a way that Bourdieu (1986) asserted, its primary interest for many collector-investors in the neoliberal era may be as an abstract and elusive repository of financial value. This is what the references to art as an asset class have long tried to signify: the cultural value that works of art are perceived to carry is being exchanged for financial value by those collectors who can afford to purchase them and can determine whether they will be deposited in a museum or in a vault. The expansion of freeports is a demonstration that more collectors are selecting offshore storage of financial assets as opposed to accruing cultural capital that they would gain from gifting art to a museum.

Thinking beyond the actions of individual collectors to focus on underlying economic developments, one way of framing the development of freeports is that they represent a convergence of state interests and neoliberal market processes since they generate exceptions to state regulation that benefit the wealthy and allow them to deposit their investments in secrecy jurisdictions. Yet many scholars have pointed out that the development of offshore banking began with the Euromarket that emerged during the capital-control financial domain of the Bretton Woods system before the emergence of neoliberalism (Shaxson 2011; Ogle 2017). Further, among freeports currently in operation, the Port Franc of Geneva has been in existence since the nineteenth century (Segal 2012) but earlier ones existed in the British, French and Dutch empires as far back as the mid-eighteenth century (Orenstein 2019). The roots of tax-free storage clearly pre-date the development of neoliberalism, even if the means to secure art in freeports has expanded more recently in the twenty-first century. The historian Vanessa Ogle explains it this way: "When the Bretton Woods system of fixed exchange rates was dismantled, a differentiated global political-legal landscape of avoidance thus was readily available" (Ogle 2017, p. 1436).

Tax-free zones that have proliferated around the world present a paradox: states have found the means of legislating to the benefit of multi-national corporations and foreign investors at the expense of their own territorial authority (Sassen 2002). This paper begins to explore freeports in this framework, at the convergence of national sovereignty and transnational economic developments in the luxury commodities markets since that is the class of objects stored in freeports in the twenty-first century. While freeports represent the success of market sovereignty to escape the control of the state, they have been legislated by states in their own interests. More importantly for this study, the market processes that they introduce have already transformed the dynamics of the art market and the proliferation of freeports, and art collectors' interest in employing them, promises to have greater impact on the art market of the twenty-first century. In other words, the processes unleashed by states that sought to act as secrecy jurisdictions have transformed traditional market structures and have generated new market effects even in the domain of art collecting where the unique qualities of an art object are the basis of its value. Freeports demonstrate how even the most recondite and valuable things can be converted into capital and harnessed for their potential to generate more value through the novel instruments of financialization.

\section{Discussion}

One major challenge is how to study freeports since their contents are kept secret. Secrecy jurisdictions have been the subject of scholarly inquiry since the 1980s, but most of it has focused upon the banking and finance domains (Sampson 1981; Palan et al. 2010; Zucman 2013). What amounts to a series of novel accounting practices to evade national legal authority has transformed from an industry of $\$ 71$ billion in 1971 that now conceals at least $\$ 7$ trillion in holdings and an additional $\$ 12$ trillion in Foreign Direct Investment assets, according to the IMF (2018). These secrecy jurisdictions represent an alternative legal order that would seem to compromise international law by preventing state regulatory authorities from being able to find information about their citizens' investments in foreign countries. The network of secrecy jurisdictions around the world generated little interest until the United States and its allies began efforts to trace terror-financing networks in the wake of 9-11. In the early 2000's, a 
series of Anti-Money Laundering directives was developed and enforced internationally and these agreements have curtailed such practices somewhat. Further, leaks from offshore facilitators, such as the Panama Papers and the Luanda Leaks, have led to greater transparency and a fascination with the illicit practices of a variety of world leaders, CEOs and even sports stars to shield their assets in secrecy jurisdictions.

This aspect of secrecy jurisdictions has led to a burgeoning field of scholarship around freeports, international law and illegally transported art works or cultural heritage (De Sanctis 2013; Elbaor 2016; Charney 2016). The longtime wars in Afghanistan and Iraq, as well as the growth of the Islamic State as a global terrorist network in Syria and Iraq, has led to considerable looting of cultural property and sales outside of those countries. Money laundering, and hiding various illegal activities, is another area of scrutiny related to the development of freeports internationally and the Geneva Port Franc is now protected by Swiss customs officials after looted Etruscan antiquities were discovered there in a raid in 2003. While the evidence presented in the scholarship on these dimensions of freeports is salacious and various telling anecdotes from the art world have emerged from the leaks already mentioned (discussed more below), the goal of this paper is not to focus on legal perspectives that seek to address and to challenge the black market in cultural heritage. Rather than focusing on black-market activities (law breaking), this analysis explores the grey market in which activities are pursued that are not formally illegal but instead stretch the domain of legality through deterritorialized spaces to offer financial incentives for art collectors to act outside of the fixed domain of international regulation. Collectors who employ freeports for tax avoidance or to ensure the greatest security for their possessions are not breaking any laws but the financial flow of goods through freeports provides new means to investigate the interaction of state-created zones of exception to transnational economic processes of neoliberal globalization. Exploring this line of inquiry will also reveal important developments in the global art market.

Since the grey market is informal (unregulated) but not illegal, it will prove useful to consider approaches developed in sociology and anthropology to examine the informal employment market, particularly its size. There are a variety of informal practices in the art market, as prior studies have shown (Velthuis 2005; Zarobell 2017) because the artist profession is one that relies on a variety of exchanges, only some of which are claimed on a tax form. This study of the market focuses instead on the way collectors operate in the margins of the art economy by storing and trading art works in unregulated zones of exception. Economists have made a variety of studies of the art market but they have not considered freeports because very little data exists to model and analyze. Therefore, attending to the longstanding history of informal markets in Anthropology and Sociology (Hart 1973; de Soto 1989; Portes 2010; Mörtenböck et al. 2015) will be more productive as a model for this study. One wants to know how much art is secreted away in freeports so it makes sense to look at comparisons to the informal economy, the unregulated and invisible economic transactions that do not turn up on a balance sheet anywhere. In other words, how big is the freeport phenomenon and what percentage of economic activity related to the art market is connected to this deterritorialized legal domain? Previous methods for studying the informal economy can be productively employed to estimate the scale of art storage and its impact on the market. In his book Economic Sociology: A Systematic Inquiry (2010), Alejandro Portes maps out various means that social scientists have developed for "measuring the unmeasurable" (Portes 2010, p. 148), meaning the size of the informal economy. There are three broad approaches provided: the Labor Market Approach, the Household Consumption Approach, and the Macroeconomic Approach.

Of the three, the Labor Market Approach is the least useful to adapt for these purposes. This model suggests that informal workers can be found by how people identify their category of work on self-disclosed national surveys, such as in tax filings and the Census. The assumption is that some categories of employment, and particularly the unemployed category, suggest that individuals are more likely to be working in an unregulated environment so economists can use these actors as a proxy to calculate informal economic activity. Of course, there is a fundamental difference between objects 
that gain value and people that make money and file taxes. Further, there is no universal registry for works of art such as social security numbers for citizens to be accounted for by their own states. (Various manifestations of blockchain technology in the art world have proposed to provide such a register but that is for another purpose.) This leaves insurance and taxation of art works as the most likely equivalent to the national survey, the best source to seek like information about the value of works of art not currently on the market.

Ostensibly, every art work of value in any country is valued for insurance purposes but it is not necessary for assessed values to be passed on to tax authorities unless it is part of a taxable category (income, gift, estate). Looking at documentation by tax authorities in the U.S. as an example, the total number of works assessed by the IRS's Art Advisory Panel in 2017 was 365 items, with an aggregate value of $\$ 233.7$ million (Art Advisory Panel Annual Summary Report 2017). The art trade in the U.S. that year was valued at more than $\$ 25$ billion (McAndrew 2018, p. 38). Art works evaluated by the Art Advisory Panel will not come close to accounting for art housed in the U.S. Without a national survey or universal registration, this approach will not be useful in measuring freeports. There is another problem to consider related to art that crosses borders and therefore ought to be accounted for.

For art, international transfers are unregulated unless duty is paid. Customs does monitor art movements, but does not provide data on inflows and outflows, unlike financial transfers. However, as a recent report on freeports to the EU Parliament explains: "In the EU, goods can be introduced to a free zone without presentation to customs and even without declaration to customs. The presence of customs in free zones is not mandatory within the EU." Further, "in the EU, there are far more customs warehouses [bonded warehouses], which can provide the same advantages as free ports, including indirect tax-deferral and secrecy, than there are free ports." (Korver 2018, p. 13). This evidence demonstrates that freeports are not so unique after all but, in fact, a number of facilities (the bonded warehouses mentioned in the EU report) can provide the same tax advantages as freeports to the Ultimate Beneficial Owner (UBO) of art works. Customs inspections that take place at freeports in Europe, in Switzerland and Luxembourg, are more the exception than the norm. Not only is customs data about art transfers not shared, it may not even be collected. The Anti-Money Laundering Directive 5 (MLD5) provides new norms within the EU as of January 2020, and these will be discussed below. Unfortunately, a review of customs authorities will not get us any closer than the tax regulatory authorities in assessing the amount of art in freeports themselves.

The second approach outlined by Portes is based on consumption and developed by the sociologist James D. Smith (1987), who used survey data from a National Probability Survey of 2100 American families about how much of their own purchases were made "on the side". Based on these numbers, Smith developed an estimate of informal economic production in the U.S. by extrapolating this survey data to encompass the entire population and their contribution to the informal economy. Survey research has become an important tool for measuring the size of the art market in recent years because, by most accounts, more than half of the transactions in the art market are made in private, and not in public auction houses that provided the data for most economic analysts of art transactions previously.

Clare McAndrew pioneered this as a means to measure the scale of the art market, meaning transactions globally over the course of a calendar year. McAndrew's surveys, originally published by the European Fine Art Fair (TEFAF) but more recently by Art Basel, have never asked about participation in freeport storage, or informal transactions, so her surveys do not shed any particular light on freeports. But Deloitte and ArtTactic have collaborated on an annual "Art \& Finance Report" that has offered some interesting data points on freeports over the years. ${ }^{2}$ In their 2014 edition, timed with the launching of Le Freeport Luxembourg, they reported that $28 \%$ of the collectors and art professionals surveyed had "a relationship with a freeport provider" and $43 / 42 \%$ of these categories

2 Both of these firms have a business interest in the art market and this provides them with invaluable connections that allows them to poll relevant collectors, and their methods are carefully discussed. Their interest in the market suggests that while the data may be soundly devised, its presentation in their reports is not exactly disinterested. 
respectively said they were "likely to use a freeport in the future" (Deloitte and ArtTactic 2014, p. 86). If we combine that 2014 data with recent data from their 2019 report that estimated of the total amount of wealth held in arts and collectibles globally is \$1.74 trillion (Deloitte and ArtTactic 2019, p. 49), one might have an idea about the value of art and collectibles held in freeports; it would be in the hundreds of billions. While the accuracy of such a calculation is discussed below, there is a missing piece of the puzzle, namely the amount of art stored (\%) by those 28 or $42 \%$ of collectors who are using freeports.

The Macroeconomic approach may also be helpful here since a number of economists have worked on calculating the amount of offshore investments held in secrecy jurisdictions (tax havens). Gabriel Zucman published an important article in 2013 in which he sought to calculate the "Missing Wealth of Nations" (Zucman 2013). Pointing to anomalies in global balance of trade statistics, Zucman attempted to discover why most affluent countries were debtor nations, and he made a convincing case that this is due to tax havens because when assets are transferred to tax havens, they turn up as liabilities leaving the countries that housed them, but they never turn up as assets in another country due to the secrecy rules of tax havens (Zucman 2013, p. 1322). His estimate for the total amount of global wealth held offshore based on his calculations of macroeconomic data is $8 \%$. Now Zucman is focusing on OECD countries and other studies (Global Financial Integrity 2020) have pointed out how much wealth escapes from Global South countries to tax havens, so it is likely that Zucman's estimate is conservative. Even so, $8 \%$ of $\$ 1.74$ trillion would be $\$ 139$ billion so if art works operate like other assets and all of these studies are accurate, the amount of art held in freeports globally would be a little more than double $(220 \%)$ of the annual turnover in art works globally ( $\$ 63.7$ billion) as calculated by McAndrew (2018).

This back-of-the-envelope calculation, combining the results of divergent studies, provides us with what we most want, an estimate of freeport assets. Yet, it is wise to proceed cautiously here. According to a 2016 article in the New York Times, a government survey reported that the number of art works in the Geneva Port Franc was more than 1.2 million, including 4500 works held by one family of dealers (Bowley and Carvajal 2016). Deloitte and ArtTactic's 2019 report also suggests that the value of works in the Geneva Freeport is between \$50-100 billion (Deloitte and ArtTactic 2019, p. 237). This is also a very conservative estimate based on the number of works reported but, if that figure is roughly accurate, the number of globally held assets in freeports must be a lot larger than \$139 billion (see interview with Yves Bouvier, this Special issue). Further, this estimate does take into account two other factors that would increase its size considerably: the existence of many more bonded storage facilities mentioned above (that outnumber freeports but provide the same services) and the black market (which equals around 20\% of the global economy in any given year and whose profits are all hidden by necessity and therefore would not be represented in any official figures).

Having considered these means of potentially determining the value of art in freeports, it becomes clear that the result of an analysis of existing data is not sufficient to ascertain the scope of the practice. In order to come to terms with how the global art market is impacted by freeports, it is necessary to acknowledge that the secrecy jurisdictions are effective in their machinations; they conceal the value of their holdings and prevent an accounting of the amount of art that has been transferred to offshore zones. It is necessary to pivot this analysis based on the lack of available data about freeports. Outside of anecdotes about certain collectors or dealers who have been "caught in the act" through the publication of leaks, very little verifiable data is available on the broader trends of hard assets stored in tax-free zones. By providing zones of exception, a handful of countries have provided the means for art and other hard assets to escape international regulation, and academic scrutiny. While these objects 
remain outside of the domain of discernable economic activity, the ability to protect them from tax laws produces economic effects that can be traced and decoded. ${ }^{3}$

Freeports exemplify broader trends in transnational economic activity but a more careful examination of the art market and the role of freeports will help to demonstrate how these processes operate. The first point to establish is that freeports operate as tax havens by severing the connecting factor between individual and asset. In Palan, Murphy and Chavagneux's study, Tax Havens, How Globalization Really Works, the authors explain that tax havens are designed to sever the connection between an individual and a "taxable event" by putting them in two separate countries, with different rules (Palan et al. 2010, p. 81). Freeports achieve the same effect, severing the owner of an art work from the tax liability that might be owed upon her asset.

Zucman's article (2013), mentioned above, demonstrates some useful information about the effects that changes in banking rules have had on trends in shifting assets to offshore tax havens. In 2005, the European Union instituted a new set of procedures (the EU Savings Directive) to deter tax evasion, so that every European owner of a bank account in Switzerland would have taxes collected on behalf of their government by Switzerland. Zucman's data clearly shows that in 2005, it is possible to detect a spike in assets assigned to companies registered in offshore tax havens with a corresponding drop in European accounts held in Switzerland. He explains this phenomenon by asserting that Europeans do hold most of the assets in Swiss bank accounts, but due to the new law, they opened shell corporations in offshore jurisdictions to avoid the tax implications of the new law.

This demonstrates that, indeed, Swiss bank accounts are being used for tax avoidance by wealthy Europeans and also that these affluent individuals have a series of choices about how to prevent their assets from being taxed and will use those secrecy jurisdictions to their advantage. Another means of avoiding tax obligations, more central to the functioning of freeports, would be to transfer savings into hard assets because freeports and bonded warehouses do not have the same reporting requirements as banks. This is exactly what a research paper by De Simone et al. (2019) argue in relation to the United States' Foreign Account Tax and Compliance Act (FATCA) rules that were passed in 2010 and went into effect in 2012-2014. This U.S. law requires foreign financial institutions to directly remit information on their account holders to the IRS, but not every country signed on to this law and it was primarily intended to reduce round-tripping investments (U.S. investors who set up foreign companies to invest in the U.S. market tax-free). These researchers discovered that while round-trip investing did drop, the law did not cause capital to return to US owners of foreign companies. In fact, many tax evaders simply shifted assets to other non-signatory countries or transferred them to other investments, such as art and collectibles, not covered by the laws. It is notable that the record for the global auction market sales was set in 2011, the year between the passage and implementation of this law. ${ }^{4}$

Both of these economic studies point to complex layers of secrecy described by Nicholas Shaxson in his 2012 book Treasure Islands but revealed in detail through the Panama Papers leak from the Panamanian law firm Mossack Fonseca. This 2016 scandal was illuminated through a series of articles by various reporters and a pair of books by Obermaier and Obermayer (2016) and by Bernstein (2017). A number of art world figures have been implicated through these links, but what has been reported is just the tip of the iceberg regarding secrecy jurisdictions and how they are used by the ultra-wealthy to shield their assets from regulatory scrutiny. Nevertheless, a series of anecdotes suggests that offshore corporations and trusts are employed to make invisible transactions of fine art that are unreported and unregulated and this accords with current research on financialization, as well as with other innovations in the art market discussed below. Many of these stories from the Panama papers concern

3 Katarina Pistor's work, The Code of Capital (Pistor 2019), provides a compelling means of rethinking how the law codes certain objects as capital and it is highly relevant to this discussion of freeports, but she does not consider them nor does she analyze offshore jurisdictions.

4 While a small minority of contemporary art works are intangible, such as web art or social practice pieces, this group of works is not a significant portion of the art market and intangible assets do not require a freeport to be stored in secret. 
works of art are held in freeports and the Nahmad family of art dealers are named as securing their art purchases in the Geneva Port Franc (Bernstein 2017; Bowley and Carvajal 2016).

What emerges from these stories are often venal efforts to protect assets and the sale of assets from public view, even when works of art are being auctioned in public. One particularly galling story involved the sale of the art collection of Victor and Sally Ganz, some of the most noteworthy modern and contemporary art collectors in New York in the second half of the 20th century. Their auction was handled by Christie's New York in 1997, at that point a publically-traded company whose largest shareholder was the British billionaire Joe Lewis. Apparently, the lion's share of their collection was sold, via the London Gallery Spink and Sons (then owned by Christie's), to an offshore company controlled by Lewis-Simsbury International-weeks before the auction. What is more, the deal set out that any value raised by the auction above the price paid by Simsbury would be split between Spink and Sons and Simsbury (Bernstein 2017).

This might sound like a shady side deal considering that the Ganz sale was supposed to be a public auction in which the value of works would be fixed in an open and fair market. Yet what was described by Bernstein in his article is none other than a third-party guarantee, albeit achieved through a unique offshore component ensuring that Lewis would not pay tax on the sale or any profits it might yield to him. One of the largest trends at auction houses in the past years has been the rise of the third-party guarantee as a means for auction houses to secure the best lots by being able to offer a price floor to the seller no matter what price a work may fetch at auction (Kinsella 2019; Crow 2019). In an industry that is very prone to rises and falls in prices based on external circumstances that no auction house can control, this is a valuable tool to appease the jittery consignors of their multi-million dollar treasures. In the deal described above, the Ganz family walks away with a guaranteed \$168 million and, presumably, some of the profits for sales achieved above this baseline as they would have been represented by Spink and Sons in this matter. As auction houses are public venues who employ the drama of the auction to wring more profits from their clientele, all of the excitement, and reporting, are directed at the lots that achieve the best prices in "record-breaking" sales. But if we want to know more about freeports and their contents, we should look instead at the bottom end of their business-what about the paintings that do not get sold and the records that do not get set?

When works of art do not sell at auction, it is said that they are "bought-in", meaning that the buyer retains the work and can sell them post-auction at a reduced price to interested parties and dealers have often used this opportunity to acquire works at cut rate for future sales. The value of the work did not reach its potential at that moment but such a dealer perceives a potential profit in the future. While this is an inherently speculative practice, it is one of the pillars of many dealers' business model and it is tied to the commercial value of the object retained as "stock". The proliferation of the third-party guarantee is nothing other than the opening up of this risk to other investors who are willing to buy a valuable painting for its minimum estimate even if no one else is willing to bid on it. The difference is that when a collector speculates on the future value of a work, it is not only the value of the object that she is banking on (its commercial potential that can be realized through a future auction sale) but the value of that work that can be put to use in the meantime minus the cost of upkeep. This is an investment decision that demonstrates an implicit conception of finance over cultural capital when it comes to art objects. Today's auction house leftovers may be tomorrow's super valuable works but they have to be stored and why not store art works in an ultra-secure environment where they will not generate a tax bill? It is only recently that this idea, long hiding in the shadows of art commerce, has become a model to market to the ultra-wealthy as the preferable way of holding assets. This convergence has led to the boom in freeports globally. The rise in income disparity that has led to the amassing of ridiculous fortunes all around the world in the past generation has combined with the rise of financialization, securitizing any asset for its tradable value and then investing that value to generate further growth. Such an argument has been made by many previous authors (Epstein 2005; Coslor and Velthuis 2012; Steyerl 2017) and it is not necessary to repeat it here, except to note that it corresponds perfectly with the anecdotes that have emerged from the Panama Papers and other leaks. 
If these anecdotes tell us something about the kinds of deals that employ offshore mechanisms in the art market, one might also ask what further financial innovations might freeports facilitate? This study aims to build on these previous ones by looking at financialization in freeports not only as a result of transformations in the market (and capital itself), but also as a driver of the art market.

Once art is in storage, reduced to a hard if delicate asset, why let its value just sit there? That would be the equivalent of having cash stashed in your mattress. Art investing is an expanding industry facilitated by freeports because they are secure, secret and tax-free, ideal conditions for the preservation of financial value. The most common form of using art as an asset is to use its value as collateral to buy more art, or other hard assets, such as collectibles or real estate. In this way, it could be said that freeports drive art investment and multiply art values by providing the credit to buy or bid on more art works that drives the price up further. This is also a practice innovated by dealers but now used much more widely. Of course, there are more complicated investment vehicles, such as the buying and selling of risk, hedges, and re-insurance, to say nothing of all of the blockchain technology start-ups that sell "tokens". It could be said that freeports are generating their own budding economy in a neoliberal capital framework, in which owners are severed from their assets (taxable events) for tax benefits but with added implications for the market.

A number of new enterprises have come into existence, many of which pool resources from various investors to buy a portion of a work of art (like stock in a company), and the blockchain company Maecenas specifically sells options for fractional ownership of art works in storage. Another new company, Malevich, offers the luxury of buying art virtually so that you can own the asset without having to worry about storage, condition issues, valuation for tax purposes or any of the rest of concerns that art collectors need to shoulder. In point of fact, art objects are challenging to own and properly caring for them to insure one's investment can mean buying the services of a variety of art industry specialists so why not do away with these complications and simply own the asset? Freeports provide these services in house which makes for greater convenience and less risk since the work of art does not need to be moved, for example, from one location for conservation to another for photography. In essence, freeports not only result from financialization in the sense that art works held for their speculative value need to be deposited somewhere. They actually contribute to this trend by providing an extraterritorial space to evade international regulation of assets while their value is siphoned off elsewhere or reinvested into the art market. The development of blockchain technology, on top of the various means of leveraging assets already mentioned, will only add to this phenomenon because it allows the value of an art work to be divided and traded endlessly among investors while retaining its unique keychain in a virtual market domain constrained by no regulations. Such a model of investing liberates owners of art works to employ the value of their assets in the most desirable way without ever having to look at those paintings. If freeports sever the owners of art objects from taxable events, financialization severs the art object from its publically-traded value, dispersing that value into a field of separately exchangeable commodities. The two operate in tandem on the same principle.

\section{Conclusions}

One of the responses to the proliferation of freeports and other tax avoidance mechanisms has been to clamp down on them in an effort to stem illicit flows of capital through Anti-Money Laundering directives. On 10 January 2020, MLD5 went into effect in the European Union (Eur-Lex 2019) and the UK parliament passed a law to keep the country compliant, impending Brexit notwithstanding. This effort to stem the flow of black money also concerns tax liability of European citizens. The law stipulates that all goods stored in freeports must disclose their Ultimate Beneficial Owner to customs authorities. The US is currently considering similar legislation and while one of the goals of these laws is to stop transfers of black money, they also have the potential to bring money back to the state itself. Freeports' role as a tax shelter for collectors amounts to net revenue loss to governments. For example, the Canton of Geneva did a study in 2014 and found that the Geneva freeport generated tax losses to the Canton of 300 million CHF annually, even though $80 \%$ of the owners of its storage spaces were 
foreign (SFAO 2014; Helgadóttir 2019). This means that most of the tax revenue losses represented by art works stored in the Geneva Port Franc are borne by other countries who do not have tax-free storage options available. While it is a basic fact that tax loopholes in the international trade system allow companies and individuals to pay less to their country of residence, freeports demonstrate how this loophole operates for the wealthiest among us to avoid financial obligations to their states. Will governments be able to stem the flow of these losses? It remains to be seen what kind of effect MLD5 will have on the art market, but the notion that it will arrest the use of freeports seems naïve at best as long as some states legislate in the interest of encouraging transnational capital flows into their countries instead of taxing the owners of those assets. While extraterritorial spaces continue to exist, international regulation will not be able to contain and tax transnational capital flows.

It can also be argued that the anti-money laundering directives are a step in the right direction and provide some reason to be hopeful because if all buyers of art objects over 10,000 euros are scrutinized and must provide identification as stipulated by MLD5, this could well deter money launderers who often hide behind third parties and trusts. Their identities must now be revealed. Further, the UK law passed in January 2020 stipulates that dealers and auction houses must operate proactively if they have any reason to suspect foul play. This legislation seeks to punish anyone, including freeport operators, who would turn a blind eye. However, there is only one freeport that will be affected by this EU legislation (Luxembourg) and this organization adhered to these regulations from its opening in 2014. The largest freeport, in Geneva, will not be constrained by them though new laws limit the length of time a work may be stored in a freeport to six months (this may be extended) and require UBOs to be listed in the Customs forms as opposed to agents (Stener 2017). Other freeports around the world have not been constrained by similar legislation so those who want to hide their assets have many other options and are likely to use them. Even if more countries pass such legislation, the offshore domain has many loopholes and new strategies are being innovated constantly to allow investors to sidestep the rules that do come into effect, such as banking laws discussed above that were passed in 2005 and 2010 by Europe and the US respectively. ${ }^{5}$ Regulations and taxes, it would seem, are for those of us who cannot afford to hire the accountants and lawyers to sever us from our assets. Like other forms of offshore investment, freeports are likely to thrive where investors can count on certain governments to provide cover in the form of secrecy. We are only beginning to understand what the economic consequences of these de-territorialized spaces might be but it is clear that financial prerogatives predominate.

The offshore economy has generated a form of path dependence in terms of tax avoidance from companies and individuals. Government revenues have fallen as a result. The fact that the wealthy can shield their accumulations from tax laws and public scrutiny is an unfortunate reality of our era and has many negative implications. The most pressing issue is not that we are returning to a time of aristocrats secreting away their treasures but that, when art becomes a basis for trading derivatives, it leaves the artist's easel and the gallerist's white cube to sit in the toolshed of the financier. What is more, with new, widely used techniques designed to avoid any state system or regulation like blockchain available, not just bankers but just about anyone can use leverage to make everything else in the world turn into financial value too. Perhaps the unique character of art has always been a pretense because such works have ever been embedded in a market. But freeports provide evidence that suggests that the market for art has shifted such that its ineffable characteristics-what makes art different from everything else-are also fungible.

Funding: This research received no external funding.

Acknowledgments: The author would like to thank Samuel Weeks for his engagement on this topic over the years and also all of the participants of "De-Territorialized "Homes" for Tax-Free Treasures: When Art Moves

5 There is a considerable literature on derivatives and finacialization in the banking industry that is relevant here but this is beyond the scope of this inquiry (see Lépinay 2011; Harrington 2016; LiPuma 2017; Birch and Muniesa 2019). 
Offshore" a panel co-organized with Weeks at the American Anthropological Association Annual Conference in November 2019.

Conflicts of Interest: The authors declare no conflict of interest.

\section{References}

Art Advisory Panel. 2017. Annual Summary Report. Available online: https://www.irs.gov/pub/irs-utl/annrep2017. pdf (accessed on 14 August 2020).

Bernstein, Jake. 2017. Secrecy World: Inside the Panama Papers Investigation of Illicit Money Networks and the Global Elite. New York: Henry Holt and Co.

Birch, Kean, and Fabian Muniesa, eds. 2019. Assetization. Cambridge and London: MIT Press.

Bourdieu, Pierre. 1986. The forms of capital. In Handbook of Theory and Research for the Sociology of Education. Edited by Richardson John. New York: Greenwood, pp. 241-58.

Bowley, Graham, and Doreen Carvajal. 2016. One of the World's Greatest Art Collections Hides behind This Fence. New York Times. May 28. Available online: https://www.nytimes.com/2016/05/29/arts/design/one-ofthe-worlds-greatest-art-collections-hides-behind-this-fence.html (accessed on 14 August 2020).

Charney, Noah, ed. 2016. Art Crime Terrorists, Tomb Raiders, Forgers and Thieves. New York: Palgrave McMillan.

Coslor, Erica, and Olav Velthuis. 2012. The Financialization of Art. In The Oxford Handbook of Sociology and Finance. Edited by Karin Knorr Cetina and Alex Preda. Oxford: Oxford University Press, pp. 471-87.

Crow, Kelly. 2019. Art Speculators Bid to Lose. Wall Street Journal. May 13. Available online: https://www.wsj. com/articles/investor-speculation-grows-in-art-auctions-11557780259 (accessed on 14 August 2020).

De Sanctis, Fausto Martin. 2013. Money Laundering through Art: A Criminal Justice Perspective. Heidelberg: Springer.

De Simone, Lisa, Rebecca Lester, and Kevin Markle. 2019. Transparency and Tax Evasion: Evidence from the Foreign Account Tax Compliance Act (FATCA). Journal of Accounting Research 58: 105-53. [CrossRef]

de Soto, Hernando. 1989. The Other Path: The Invisible Revolution in the Third World. New York: Harper \& Row.

Deloitte and ArtTactic. 2014. Art \& Finance Report 2014. Available online: https://arttactic.com/product/artfinance-report-2014/ (accessed on 14 August 2020).

Deloitte and ArtTactic. 2019. Art \& Finance Report 2019. Available online: https:/arttactic.com/product/artfinance-report-2019/ (accessed on 14 August 2020).

Elbaor, Caroline. 2016. Freeports Come under Scrutiny by UNESCO as Havens for Stolen Cultural Property. Artnet News. October 10. Available online: https://news.artnet.com/art-world/unesco-holds-meeting-freeportsstolen-cultural-property-694412 (accessed on 10 August 2020).

Epstein, Gerald A. 2005. Financialization and the World Economy. Cheltenham: Edward Elgar Publishing, Incorporated.

Eur-Lex. 2019. DIRECTIVE (EU) 2018/843 of the European Parliament and of the Council of 30 May 2018. Available online: https://eur-lex.europa.eu/legal-content/EN/TXT/?uri=CELEX\%3A32018L0843 (accessed on 14 August 2020).

Ford, Tamasin. 2019. Hidden Art. BBC Podcast. December 3. Available online: https://www.bbc.co.uk/sounds/ play/w3csy7f6 (accessed on 14 August 2020).

Global Financial Integrity. 2020. Trade-Related Illicit Financial Flows in 135 Developing Countries, 2008-2017. Available online: https://gintegrity.org/report/trade-related-illicit-financial-flows-in-135developing-countries-2008-2017/ (accessed on 14 August 2020).

Harrington, Brooke. 2016. Capital without Borders: Wealth Managers and the One Percent. Cambridge and London: Harvard University Press.

Hart, Keith. 1973. Informal Income Opportunities and Urban Employment in Ghana. Journal of Modern African Studies 11: 61-89. [CrossRef]

Helgadóttir, Oddny. 2019. "The New Luxury Freeports" Offshore storage, tax evasion, and 'invisible' art". Paper presented at American Anthropological Association Annual Conference, Vancouver, BC, Canada, November 20.

Horowitz, Noah. 2011. Art of the Deal: Contemporary Art in a Global Financial Market. Princeton: Princeton University Press. 
IMF (International Monetary Fund). 2018. Piercing the Veil. Available online: https://www.elibrary.imf.org/ view/IMF022/25185-9781484357415/25185-9781484357415/25185-9781484357415_A016.xml?language=en\& redirect=true\$\delimiter"026E30F\$ (accessed on 14 August 2020).

Kinsella, Eileen. 2019. Auction Guarantees Lifted the Art Market to Record-Breaking Heights. The Only Problem? The Golden Age of Guarantees Is Over. Artnet. November 11. Available online: https: //news.artnet.com/market/auction-guarantees-bubble-pop-1698762 (accessed on 14 August 2020).

Korver, Ron. 2018. Money Laundering and Tax Evasion Risks in Freeports. PE 627.114-October 2018. Brussels: EPRS (European Parliamentary Research Service).

Kosmides, Michael. 2019. The Art of Disguise. Money Laundering Bulletin (29 May 2019). Available online: https: //www.moneylaunderingbulletin.com/industries/highvaluedealers/the-art-of-disguise-135238.htm (accessed on 14 August 2020).

Lépinay, Vincent. 2011. Codes of Finance. Princeton and London: Princeton University Press.

LiPuma, Edward. 2017. The Social Life of Financial Derivatives: Markets, Risk and Time. Durham and London: Duke University Press.

McAndrew, Clare. 2018. The Art Basel and UBS Global Art Market Report. Basel: Art Basel.

Mörtenböck, Peter, Helge Mooshammer, Teddy Cruz, and Fonna Forman, eds. 2015. Informal Market Worlds. The Architecture of Economic Pressure. Rotterdam: NAI010 Publishers, 2 vols.

Nixey, Catherine. 2019. Not for Show. Tortoise Media. June 1. Available online: https://members.tortoisemedia.com/ 2019/06/01/dirty-art-piece/content.html?sig=jVzeINsOzSuYXOvvrlZENuo8CT6JOWPU4Jt9T5OPAqM\& utm_source=Twitter\&utm_medium=Social\&utm_campaign=1June2019\&utm_content=Dirty_Art (accessed on 14 August 2020).

Obermaier, Frederik, and Bastian Obermayer. 2016. The Panama Papers: Breaking the Story of How the Rich and Powerful Hide Their Money. London: Oneworld publications.

Ogle, Vanessa. 2017. Archipelago Capitalism: Tax Havens, Offshore Money and the State, 1950s-1970s. American Historical Review 122: 1431-58. [CrossRef]

Orenstein, Dara. 2019. Out of Stock: The Warehouse in the History of Capitalism. Chicago and London: University of Chicago Press.

Palan, Ronen, Richard Murphy, and Christian Chavagneux. 2010. Tax Havens: How Globalization Really Works. Ithaca and New York: Cornell University Press.

Pistor, Katharina. 2019. Code of Capital: How the Law Creates Wealth and Inequality. Princeton: Princeton University Press.

Portes, Alejandro. 2010. Economic Sociology: A Systematic Inquiry. Princeton: Princton University Press.

Sampson, Anthony. 1981. The Money Lenders: Bankers and a World in Turmoil. New York: Viking Press.

Sassen, Saskia. 2002. Locating cities on global circuits. Environment and Urbanization 14: 13-30. [CrossRef]

Segal, David. 2012. Swiss Freeports are a Home for a Growing Treasury of Art. New York Times. July 21. Available online: https://www.nytimes.com/2012/07/22/business/swiss-freeports-are-home-for-a-growing-treasuryof-art.html (accessed on 14 August 2020).

SFAO—Swiss Federal Audit Office. 2014. Free Ports and Open Customs Warehouses. An Evaluation of Licensing and Inspection Activities. Available online: https:/www.efk.admin.ch/images/stories/efk_dokumente/ publikationen/evaluationen/Evaluationen\%20(45)/12490ZF_e.pdf (accessed on 14 August 2020).

Shaxson, Nicholas. 2011. Treasure Islands: Uncovering the Damage of Offshore Banking and Tax Havens. New York: Palgrave Macmillan.

Smith, James D. 1987. Measuring the Informal Economy. Annals of the American Academy of Political and Social Science 493: 83-99. [CrossRef]

Stener, Katie L. 2017. Dealing with Laundering in the Swiss Art Market: New Legislation and its Threats to Honest Traders. Case Western Reserve Journal of International Law 49: 351-72.

Steyerl, Hito. 2017. Duty Free Art: Art in the Age of Planetary Civil War. London: Verso Books.

Velthuis, Olav. 2005. Talking Prices: Symbolic Meanings of Prices on the Market for Contemporary Art. Princeton: Princeton University Press.

Zarobell, John. 2015. Art as Asset: Financialization and the Art Market. San Francisco Arts Quarterly. June 11, p. 20. Available online: https://www.sfaq.us/2015/06/art-as-asset-financialization-and-the-art-market/ (accessed on 10 November 2020). 
Zarobell, John. 2017. Art and the Global Economy. Oakland, Los Angeles and London: University of California Press. Zucman, Gabriel. 2013. The Missing Wealth of Nations. The Quarterly Journal of Economics 2013: 1321-64. [CrossRef]

Publisher's Note: MDPI stays neutral with regard to jurisdictional claims in published maps and institutional affiliations.

(C) 2020 by the author. Licensee MDPI, Basel, Switzerland. This article is an open access article distributed under the terms and conditions of the Creative Commons Attribution (CC BY) license (http://creativecommons.org/licenses/by/4.0/). 